XIV Российская национальная конференция по сейсмостойкому строительству и сейсмическому районированию (с международным участием). Сборник материалов

УДК 69.058; $624.04+699.84$

DOI 10.37153/2687-0045-2021-14-66-68

\title{
ВИБРОДИНАМИЧЕСКИЕ ИСПЫТАНИЯ ЗДАНИЯ ИЗ ЛЕГКИХ СТАЛЬНЫХ ТОНКОСТЕННЫХ КОНСТРУКЦИЙ
}

Кыштобаев Э. Дж., Инженер-расчетчик, инженер-конструктор ОАО «Промпроект». Бишкек, Kыргызстан, e-mail: emil.kyshtobaev@gmail.com

Абдыкалыков Д.Б., Аспирант МУИТ, координатор по производству «МАЭСС». Бишкек, Kыргызстан, e-mail: abdykalykov_17@mail.ru

Абдыкадыров А.3., Генеральный директор строительной компании «KARKAS.KG»

Аннотация: В докладе представлены результаты вибродинамических испытаний двухэтажного здания из легких стальных тонкостенных конструкций, а также оценка эффективности проектных решений. Также в докладе освещен обзор анализа выполненной работы, даны оценки запасов прочности конструкций и возможности применения данных конструкций в строительстве на территории Кыргызской Республики.

Ключевые слова: экспериментальные исследования, вибрационные испытания, легкие стальные тонкостенные конструкции, сейсмические воздействия, микросейсмы, динамические характеристики, спектральный анализ, сейсмические нагрузки, расчетные нагрузки, инструментальные записи, горизонтальный перекос

\section{VIBRATION DYNAMIC TESTING OF A BUILDING MADE OF LIGHT WEIGHT STEEL THIN-WALLED STRUCTURES}

Kyshtobaev E.D., Engineer constructor OJSC "Promproekt". Bishkek, Kyrgyzstan, email:emil.kyshtobaev@gmail.com

Abdykalykov D.B., Graduate student IntUIT, production coordinator «IAEEE». Bishkek, Kyrgyzstan,e-mail: abdykalykov_17@mail.ru

Abdykadyrov A.Z., General director of a construction company «KARKAS.KG»

Abstract: The report presents the results of vibrodynamic tests of a two-storey building made of light steel thin-walled structures, as well as an analysis of design solutions efficiency. The report also highlights an overview of the analysis of the work performed, estimates of the safety margins of constructions and the possibility of using these structures in building industry of the Kyrgyz Republic are given.

Keywords: experimental research, vibration tests, light steel thin-walled structures, seismic actions, microseisms, dynamic characteristics, spectral analysis, seismic loads, design loads, instrumental recordings, horizontal deflection

\section{Основная часть}

История строительства зданий и сооружений из легких стальных тонкостенных конструкций в Европе, США, Канаде и других странах дальнего зарубежья насчитывает 
XIV Российская национальная конференция по сейсмостойкому строительству и сейсмическому районированию (с международным участием). Сборник материалов

уже более 50 лет. Постепенно данный вид строительных конструкций набирает популярность и на рынке стран СНГ, в том числе в Кыргызской Республике.

Препятствием на пути применения зданий из ЛСТК в Кыргызской Республике, территория которой относится к районам с высокой сейсмической активностью, является отсутствие методики расчета холодногнутых тонкостенных профилей в отечественных национальных нормативных документах.

Некоторые международные и зарубежные нормативные документы (например, Еврокоды, а также нормы США и Турции) содержат методику расчета холодногнутых тонкостенных профилей, учитывающую специфические особенности их поведения при статических и сейсмических нагрузках.

Поэтому в настоящее время основным условием внедрения зданий и сооружений из ЛСТК в практику сейсмостойкого строительства могут являться оценки их прочности, жесткости и сопротивляемости сейсмическим воздействиям, основанные на результатах экспериментальных исследований.

Наиболее распространенным видом экспериментальных исследований сейсмостойкости натурных зданий в странах СНГ являются вибрационные испытания. Подобные испытания проводятся уже более 40 лет.

В странах бывшего СССР было испытано большое количество зданий и сооружений различных конструктивных систем. Опытные данные, полученные при этих испытаниях, позволили существенно обогатить и уточнить представления специалистов об особенностях поведения конструкций зданий при реальных сейсмических воздействиях, а также осуществить прогнозирование их ожидаемого состояния после сильных землетрясений.

Наибольший вклад во внедрение вибрационного метода испытаний в практику исследований, связанных с изучением сейсмостойкости зданий и сооружений, был внесен работами Г.Н. Ашкинадзе, М.У. Ашимбаева, Т.Ж. Жунусова, И.Е. Ицкова, Л.Ш. Килимника, А.М. Курзанова, Ю.А. Симона, Г.А. Шапиро и др.

Результаты проведенных испытаний позволили значительно повысить объективность представлений о сейсмостойкости зданий различных конструктивных типов и особенностях их нелинейного деформирования при динамических воздействиях.

Однако появление новых конструктивных систем и строительных конструкций, а также изменение представлений об интенсивности и особенностях ожидаемых сейсмических воздействий вызывает необходимость дальнейшего продолжения экспериментальных исследований.

Сказанное выше представляет особую актуальность для Кыргызской Республики, в которой за последние годы не только появились здания, имеющие принципиально новые конструктивные решения, в частности из холодногнутых тонкостенных профилей, но и существенной корректировке подверглись нормы проектирования в сейсмических районах.

Наше исследование было сконцентрировано на результатах вибрационных испытаний двухэтажного здания из ЛСТК, построенного на специальной платформе с использованием вибромашины инерционного действия в г. Бишкек.

Испытания были проведены специалистами Международной ассоциации экспертов по сейсмостойкому строительству («МАЭСС») при участии специалистов АО «КазНИИСА» в период с 27.09.2019 по 15.10.2020 года.

Основной целью испытаний и дальнейших исследований являлись экспериментальная проверка сейсмостойкости двухэтажных зданий из ЛСТК и оценка эффективности их проектных решений.

Задачами выполненного исследования являлись: 
XIV Российская национальная конференция по сейсмостойкому строительству и сейсмическому районированию (с международным участием). Сборник материалов

- определение фактических динамических параметров изучаемого здания из ЛСТК и выявление влияния на него интенсивности внешних нагрузок;

- изучение состояния конструкций объекта испытаний при динамических нагрузках, близких по величинам к расчетным нагрузкам;

- оценка прочности и способности к пластическому деформированию зданий из ЛСТК при горизонтальных динамических нагрузках типа сейсмических;

- оценка влияния наружной обшивки здания на его сопротивляемость нагрузкам типа сейсмических;

- прогнозирование состояния двухэтажных зданий из ЛСТК при реальных сейсмических воздействиях интенсивностью семь, восемь и девять баллов.

\section{Заключение}

Полученные результаты исследования свидетельствовали о наличии в двухэтажном здании существенных резервов прочности по отношению к расчетным сейсмическим нагрузкам. Общее состояние двухэтажного здания-представителя после интенсивных колебаний можно оценить как соответствующее концепциям, положенным в основу действующих норм по проектированию зданий и сооружений в сейсмических районах. Основываясь на комплексном анализе результатов испытаний и расчетов, можно резюмировать, что здания из ЛСТК высотой до трех этажей включительно с конструктивными системами, соответствующими объекту испытаний, могут быть рекомендованы для возведения на площадках сейсмичностью семь - девять баллов.

\section{Список литературы}

1. Вибрационные испытания зданий. Под ред. Г.А. Шапиро. - М.: Стройиздат, 1972. -160 с. (Гос. Ком. По делам строит. и арх. при Госстрое СССР. ЦНИИЭП жилища).

2. Отчет по результатам вибродинамических испытаний систем навесного вентилируемого фасада торговой марки NORDFOX со следующими видами облицовки: а) фиброцементные панели; б) HPL панели; в) натуральный камень; г) клинкерная плитка с затиркой швов, с заключением о возможности их применения в сейсмических районах АО «КазНИИСА».

3. СП КР 20-02-2018 «Сейсмостойкое строительство».

4. СН КР 22-01:2018 «Оценка сейсмостойкости зданий существующей застройки».

5. Шаблинский Г.Э., Зубков Д.А. Мин-во образования и науки Росс. Федерации, ФГБОУ ВПО «Моск. гос. строит. ун-Т». - М.: МГСУ, 2012. - 484 с.

6. Рекомендации по натурным исследованиям и постоянным наблюдениям за вибрацией гидротехнических сооружений электростанций II 73-2000 ВНИИГ.

7. DOI: 10.33942/sit020 Д.Б. Абдыкалыков. Экспериментальные вибродинамические исследования зданий и сооружений в условиях Кыргызстана. 